\title{
Care as you like it: the construction of a consumer approach in home care in Denmark
}

\author{
Tine Rostgaard \\ SFI - The Danish National Centre for Social Research \\ Email: TR@sfi.dk
}

\begin{abstract}
The free choice of a home-care provider was introduced in Danish home care in 2001. This article discusses the overall premises for the introduction of free choice in home care and how it constitutes an overarching response to the crisis of the welfare state. The government at that time intended free choice to lead to more user-led services, more cost-efficient services, and the development of a care market, all in line with its ideology. The article argues that to achieve these ambitions, the government introduced many new but implicit assumptions about the role and the responsibilities of the user of care. On the basis of qualitative interviews with elderly users, care workers, and care assessors, the article examines these assumptions and their implications for the user. The findings show that most users desire continuity in care more than the opportunity to 'exit' a care relationship. Moreover, users do not rate quality any higher in the private for-profit sector than in the public. The article concludes that consumerism is in Denmark now part of the logic of governance, thereby changing the conditionality of the welfare state and its subjects, and creating new forms of risks, responsibilities, and dependencies.
\end{abstract}

Keywords: choice, home help, Denmark, consumerism, elderly

\section{Introduction}

In 2003, a Liberal-Conservative government introduced the free choice of provider in Danish home care in order to improve user autonomy and care quality, to cut costs, and more implicitly to encourage the development of a market in care. From this point onwards, local authorities had to ensure that private for-profit providers of home care operate along side municipal 
providers. Elderly (and other users of home care) can in most municipalities today choose between the two types of provider once an assessor employed in the municipality has evaluated their needs. The service has continued to be free of charge and the number of care hours remains the same, regardless of which provider is chosen.

The Minister of Social Affairs at that time claimed the following:

The introduction of free choice has given dignity of the elderly pride of place, simply because from now on they will be able to exercise a choice, rather than merely use the municipal standard service offer. For the government it is simply how we view human nature. (Henriette Kjær, former Minister of Social Affairs; author's translation)

This statement illustrates that the policy of introducing a consumer choice between public and private for-profit providers of home care in Denmark intended to constitute a change of governance, which reflected a perspective of human nature that coupled human dignity with the possibility of exercising choice. However, as this article argues, the introduction of choice is a logic of governance that appears to be multi-functional and goes well beyond concerns about individual human dignity. The introduction of choice acts as an overarching policy strategy in the wake of overall criticisms of the failures of the welfare state and seeks this regime's modernization. This is not restricted to Denmark. 'Choice' has in many European countries become a major buzzword in political rhetoric, along with others such as 'user-involvement', 'participation', 'empowerment', and 'active welfare citizenship' (Evers, 2003). Along with competition, contracts, and cost control, free choice is an important component of the institutional and organizational reforms inspired by New Public Management (NPM), which have affected the public sector in many countries in recent years (Vabø, 2009; Pollitt \& Bouckaert, 2000). The search both for more diversity and pluralism in service orientation and practice and for greater efficiency and effectiveness works surprisingly well with the governmental desire to confer more power on users. Thus, at least on the surface, no disparity or conflict between these goals appears to exist.

Choice has in Denmark been an element of reforms of various policy areas since the late 1990s, particularly within care for the elderly. The focus of this article, home help for the elderly, has been the political test case of the introduction of the Danish version of choice. The elderly have been provided with what is called a 'free choice' between a public and a private for-profit home help provider(s). While other countries have introduced the choice of provider of home help as a voluntary option for the municipalities in recent years (see e.g., Blomberg et al., 2000; Blomqvist, 2004; Edelbalk \& Svensson, 2004; Rønning, 2004; Stevens et al., 2011), Denmark has gone further and made it obligatory for the municipalities to enter into contracts with for-profit providers, and almost all municipalities today offer this choice. In Denmark, the government has framed the choice as being directly related to gains of efficiency and improvement of quality, while toning down its more political and ideological preference for privatization. By focusing on the user of care services, this new policy promised to introduce more empowerment and more individualized services. Little, however, was said about whether increased user-involvement would change the care relationship between care recipient and care provider, and if change were to occur, what might be the results.

This article aims to investigate both the reasons for the government's introduction of free choice of home-care provider and its description of the shape it was to take. The aim is first, on a more theoretical level, to 
understand how the introduction of free choice is situated in the overall modernization of the welfare state. Secondly, the aim is to investigate after the introduction of free choice the expectations attached to roles and relationships that were communicated to the elderly as recipients of home care. This aspect is illustrated by statements of users of home care, care workers, and care assessors. The article thus examines the implicit assumptions about the elderly as users in the consumerist model in regard to the identification of need, quality, and possibilities for expressing satisfaction through the exit or entry into provider organizations.

This article is based on qualitative interviews with users of private for-profit and public home care, care workers working in public or private for-profit home-care sectors, and care assessors employed with the municipality. Interviews were conducted in four Danish municipalities (Bogense, Kalundborg, Søllerød, and Århus) in 2007. In all, 18 individual interviews and 14 focus-group interviews were carried out. Observational studies were also applied.

This article argues that the initial notions of welfare-state failure have given way to a new regime of consumerism in Denmark. Free choice was the allembracing answer to many of the paradoxes of the welfare-state crisis: it was supposed to result in better user-led quality of care, and to provide more costefficient services, and it was intended to develop a care market, in line with the ideology of the present government. Free choice seems to introduce new rights of equality, making everyone entitled to choice and giving the user a new active role. The argument presented here, however, is that the elderly themselves desire continuity in care, not the possibility of exiting and thus ending care relationships. Moreover, free choice in care overlooks the crucial point, that care work involves relationships, trust, and dependency, and thus care cannot be viewed as simply another commodity.

\section{The crisis of the professionalized welfare state - where to go from here?}

The introduction of free choice in Danish social policy is part of a strategy to respond to criticisms of the welfarist approach, with its standardized products, top-down decision-making, and the automatic acceptance of the judgment of professionals (Evers, 2003). Free choice, however, has also been part of a Danish political and ideological project to introduce more market mechanisms into the public welfare sector. One important factor contributing to the demands for more free choice has been the underlying assumption that the welfare state in its present form has failed. A look at the internal ${ }^{1}$ challenges to the welfare state reveals at least three general explanations for this welfarestate failure of legitimacy and governance, all of which are also consistent with the criticisms of the Danish welfare approach.

First, some scholars invoke the theory of systemic overload, as social problems have become increasingly politicized and made public, and demands are often contradictory and of both economic and political concern (e.g., the lack of producer efficiency, the failure to meet user demands, and the lack of service innovation) (Clarke \& Newman, 1997). The theory of systemic overload has also been a driving factor behind Danish modernization

\footnotetext{
1 For external shocks to the welfare state, see e.g., Pierson (2007) Beyond the Welfare State? Polity Press: London.
} 
reforms, which have focused on increased professionalization, accountability, control, equity, cost-efficiency, and more (Melander, 2008).

Secondly, there are researchers who note a conflict between equality that is a political promise of the universal welfare state and the actual welfare outcome (Højlund, 2002), especially as decentralization is very pronounced in the Scandinavian welfare states. This phenomenon has led Kröger (2009), amongst others, to argue that the Scandinavian countries have 'welfare municipalities' rather than a welfare state, with a single and uniform welfare approach. Until 2007, in Denmark alone, 275 local municipalities were in charge of social care; after a re-structuring reform they are now down to 'only' 98. The local approach is especially pronounced within social-care services, where local politics result in different welfare policies, provisions, and outcomes, which is exemplified, for example, in the variation in public spending for elderly care across municipalities (Lolle, 1999). The social-care services are also policy areas in which needs are very individual and therefore difficult to generalize. The same care need may result in different welfare responses across local areas, and the need for social care for two people, despite their having similar social problems, may also be perceived differently. Although the Danish welfare system is based on this decentralized approach, the welfare state is nevertheless not able to deliver uniform, equal outcomes.

Thirdly, some scholars see a conflict between ensuring autonomy and legitimizing public intervention in private affairs for a higher social purpose. This is a classic clash between social-liberalist assumptions about the legitimacy of intervention in matters of lifestyles, family formation, choice of education and work, and more, and a more liberal assumption of the sovereignty of the individual (Højlund, 2002) - where the latter has been especially successful in advocating for choice, while emerging individualization has been a driving factor favouring the individualist approach. Other forces have also fostered this development, through the increasing dominance of bureaucratic logic and consumer-market logic (Kremer, 2006). The consumerist approach obviously breaks with previous assumptions that only professionals should define need. The accommodation of participation and empowerment of the user has thus gone hand in hand with increasing criticism of the previously unchallenged dominance of professionalism. Not only should users have a stronger voice in the decision-making, but there should be better political control and accountability of the work done by professionals, and it should be paid by the public (Foster \& Wilding, 2000). Dybbroe (2008, p. 44) notes that this increasing political and institutional control in the care sector has in fact led to a standardization and manualization of the care work. According to her, this development results in a de-qualification of care workers since work is now 'less dependent on the learning and development of the care worker and more dependent on political and institutionally directed constructions of caring practices'. The increased participation and empowerment of the user has, however, been of more concern, and the Liberal-Conservative government that took office in 2003 saw free choice as a way of accommodating such individual preferences. The following statement exemplifies this view:

With the free choice, the individual can better influence his/her own life, and at the same time citizens will experience a more attentive public sector, with a focus on individual wishes and needs. (Regeringen, 2002, author's translation) 


\section{Welfare reform in a social-democratic welfare regime: entering free choice}

Free choice is an appealing strategy as it appears to offer the possibilities of both introducing more user empowerment and signalling political innovation and responses to criticisms of a lack of equality and individualism. In Denmark free choice between a public and private for-profit provider has, therefore, been a central element of many reform strategies since the late 1990s. Initially, launched by the Conservative government in 1991 in the health-care sector as part of a strategy of marketization and privatization, ${ }^{2}$ the free choice of public and private for-profit providers was a response to critics who claimed that the health system was both ineffective and too costly, claims that were by then universal in most welfare states.

The notion of free choice soon proved persistent in the Danish political rhetoric, including with the Social-Democratic government that came to power in 1992. However, the party backbenchers demanded stronger opposition to privatization and outsourcing, viewing both as antithetical to the very essence of social-democracy. The government decided, therefore, that basic services such as home help were to remain within the public sphere. Thus in contrast to the Swedish reforms in the early 1990s that allowed the privatization of home help as part of the economic-crisis package, Denmark continued its public provision of home care into the new millennium.

\section{The form of free choice in home help}

However, when a Liberal-Conservative government came into office in 2001, free choice was placed on the agenda as part of its overall NPM strategies. Since then, the choice option has spread to other policy areas, as a fundamental element in the modernization of the welfare state (Greve, 2004). For the elderly who live in their own home, the introduction in 2002 of free choice initially encompassed only practical care assistance, such as help with cleaning, shopping, and doing the laundry. Personal care, such as help with bathing and getting dressed, was not included, and continued to be provided by the public home-help providers. This distinction in the free choice clearly reflected the legacy of Social-Democratic welfare ideas, that the privatization of these kinds of intimate services as personal care was inappropriate.

In 2003. ${ }^{3}$ however, the Liberal-Conservative government decided to include personal care in the drive for free choice. Private for-profit providers thus today offer the same services as public providers and also provide services around-the-clock. In addition to basic personal care and assistance with practical tasks, private for-profit providers can also offer what is called additional services, such as gardening, window polishing, snow clearing, or simply time to sit and chat, as is shown in one of the illustrations from the interviews with private home-help providers below. All of these services are charged.

In order to increase the number of private for-profit providers, local councils are now obliged by law to ensure that these providers operate in the municipalities. In turn, municipalities must enter into contracts with private forprofit companies, along with the municipal home-help services, so that the

2 See also Rostgaard, 2006 for a more extensive account of the introduction of free choice in home care.

${ }^{3}$ Lov nr. 399 af 6 . juni 2002 Frit valg af leverandør af personlig og praktisk hjælp [Free choice of provider of personal and practical help]. 
elderly can choose between one or more private and public providers. While the provision of home help remained free of charge, regardless of who provides the care or how many hours were provided, private for-profit companies can charge for extra services such as window cleaning. The process for receiving help has remained the same. The elderly are still assessed by a care assessor who is employed in the municipality according to the same needs-assessment criteria as before. However, with the introduction of a purchaser-provider split these assessors today no longer operate from the same premises as the public home-help provider.

By 2010, 611 private for-profit home care companies were operating in Denmark, and only four out of 98 municipalities had no private for-profit provision of home help. Excluding Copenhagen, which has 57 private for-profit companies, on average six companies operated in each municipality offering free choice, with urban areas having the highest concentration of providers (Danmarks statistik, n.d). In the spring of 2011, in order to stimulate the privatization of social care, the government debated whether in some municipalities the implementation of free choice should also exclude public providers, so that in those municipalities only private for-profit providers would operate.

\section{Construction of a consumer approach - what are the assumptions?}

Several political arguments support the decision to introduce more choice for users. First of all, free choice constitutes a timely answer to the requests for more individualized welfare solutions in that it can accommodate what the Ministry of Finance sees as 'the citizen who increasingly views her/himself as set free from both the close and the larger communities, and therefore places more individual and critical demands to society, including to the public services' (Finansministeriet, 2002, author's translation). Secondly, free choice breaks with the former public monopoly of service provision, thereby ensuring a more efficient and improved care provision. According to traditional assumptions about the market mechanism, the quality of care should improve as providers compete and as users gain influence through their choices. Nonetheless, the question remains of what implicit assumptions there might be in the drive for free choice with regard to the role and responsibilities of the user and the purpose of care provision, as viewed from the perspective of elderly users, care workers, and care assessors.

\section{A new focus - the active user}

At the heart of free choice lies the assumption of the autonomous user. The ageing population is expected to be increasingly more diverse and individualized, and presumably will require more diversified welfare solutions that give the user more say in the organization of care. This assumption underpins the views that proponents of free choice hold, even though users in most Danish user surveys pre-dating the introduction of free choice expressed satisfaction with the public provision of welfare. Such satisfaction is in contrast to the introduction of choice in other countries, where powerful organizations representing people with disabilities demanded more choice (e.g., Stevens et al., 2011). Still, the government believed that free choice would make the citizen more satisfied and more autonomous, whether he or she actually exercised this option (Kommunernes Landsforening, 2004; Finansministeriet, 2002). 
Thus, care now has a new function: the organization of care must not only ensure that the cared-for receives what they need, but it must also contribute to the users' autonomy. As care provision becomes user-led, not provider-led, the needs of the user are to lie at the centre, requiring the user to become more active. Users need to identify what - for them as individuals - is the best organization of care and they must express this decision through the choice of provider. The new care regime thus assumes that the user is no longer a passive care recipient but an active one.

\section{Easy exit}

The user in this way becomes a consumer with the possibility of 'shopping elsewhere' if he or she so desires. The choice itself provides him or her with influence and ensures that the care organization listens to him or her. There are in principle no constraints on the individual's exercise of consumer power, and he or she is obliged to make a choice of provider, but can choose a new provider as often as he or she pleases. As Jon, a care assessor, expresses it, the 'choice technology' is easy to operate. It only involves contacting the municipality if one wishes to change provider:

And now there is a free choice, and many calls us - and they just need to call and say that they would like to change provider, and then we help them. (Jon, care assessor, author's translation)

The introduction of choice thus presumes the existence of an easy and real opportunity for exiting, a choice that enables users to express dissatisfaction in a new way.

\section{Less complex identification of quality}

In the municipalities, users are then observed how they exercise the choice, as a way of understanding users' preferences for the organization of care. In this way, municipal home-care organizations, local politicians, and administrators find it less complex to observe how specific users wish to see care provided. The administration statistics on the share of users using forprofit providers and municipal providers, and more importantly, any changes in this distribution, the municipality uses as a guideline of user preferences, pinpointing which provider has provided good-quality care.

In this way, the choice option also serves as a complexity reducing technology. From a political and administrative perspective, the identification and determination of how well the home-care organization is performing becomes less complex with respect to the offering of services in accordance with user preferences. Previously, such information was difficult to obtain because it required, for example, user-satisfaction surveys. Now, the municipality simply interprets users' patterns of entry into and exiting from public and private services as an important indicator of whether various homecare providers are doing their job properly.

Consequently, users need to understand that choice is something that is observed and interpreted. The 'competent' consumer would, therefore, act differently from Michael, who says: 'I think it is a rather big company, but it was purely accidental that we chose them. Or perhaps we asked the care assessor in the municipality, that might be it (Michael, user of private for-profit home care, author's translation). 


\title{
Common learning
}

The implicit expectation is that choice not only implies a movement between some constant alternatives (the private for-profit or the municipal provider), but choice should also help develop the quality of care, in that the various providers will learn from one another. The user is expected to choose the best alternative, and the provider is expected to consider why it was chosen or not. Providers are in this way expected to gain the opportunity to learn from one another by being inspired, thereby contributing to a general upgrading of the quality of care. As Anne, who works as a home helper in a private for-profit home care organization, expresses it:

\begin{abstract}
I have experienced that those who receive municipal care, they also receive better municipal care after we entered the market. Now they [the municipality] suddenly need to deliver better services, and that must in the end benefit the elderly. So, things being equal, I think...that it is a good idea, because we need some competition. (Anne, private home helper, author's translation)
\end{abstract}

Choice thus not only ensures that the user has an opportunity help weed out poor quality providers, but also demands that care organizations that are not chosen learn and develop according to user preferences.

\section{Setting the user free - but obliged to choose}

Although free choice allows the user to choose his or her own provider, the user is also obligated to make a choice. In other words, the user has the right to choose but no right not to choose. All users must make a choice when the care assessor comes to visit:

What I do, when I visit an older person, is to bring three booklets explaining the free choice option. I take them out, when I sit with the citizen, and I say 'You have received these by mail. Have you thought about what you want to answer? (Kirsten, care assessor, author's translation)

Cathrine, a care recipient, says that the municipality involved in communicating free choice to her suggests that it is legitimate to choose a provider other than the public one:

You see, I received this form where you could choose. So in a way, it is the municipality that appreciated it that we can choose between a public and a private provider. (Cathrine, municipal care recipient, author's translation)

While in principle the care assessor must not make the choice for the user, many users are highly reliant on the care assessor to make the choice, as in Michael's case. NPM-remodelling strategies also imply a change in the daily organization of care and a pre-condition for the outsourcing of care is often that the organization of care assessment and care provision is split (Trydegård, forthcoming). Following the introduction of this purchaser-provider split, care assessors in Denmark today also operate from office facilities separate from those of the public home-help providers, and in principle should favour any providers. Little, however, is known about whether care assessors assist the elderly in making the choice of provider, and if they do, how. 
Moreover, making the choice can be difficult. As Anja, a care assessor, noted:

I often experience that [older citizens] think that it is difficult to choose. 'Can't you do it?', they say. But then...then I leave [the brochures] in their home, and then they can have a look and call me when they have...maybe they call round and see whether they [the providers] can cater to some special needs which they [the older citizens] may have... (Anja, care assessor, author's translation)

The elderly in this way are expected to take action and to seek more information, perhaps by contacting other providers and asking about what they offer. Essential for the proper functioning of the choice option as a complexreducing technology is that choices are not made randomly, but on the basis of careful considerations of where the best quality lies. As an autonomous user, the elderly individual is, therefore, expected to seek information that allows him or her to differentiate between the different service providers and to make a choice based on an assumption about which provider is best.

\section{The new expert of needs and quality}

Users are now the ones who decide what is best for them; if they find that the care is not according to their liking or if they disagree with the care worker's approach, they can choose another provider organization. This user power makes the user the expert, as with the principles of consumerism, and transfers some of the identification of need and of the right form of care to the user, which is formally the last link in the care chain. In contrast, the professional care worker loses some say and can be challenged about his or her opinions. Hanne and Sanne, who both work as privately employed home helpers, commented on these changes:

It is sort of, when they are with the municipality, they are assigned something, but when they are with us, they are the ones to decide. It's the mentality. (Hanne, author's translation)

They become sort of the employer. Yeah, that's the right word, I will use. Masters in their own house. 'I'm the one living here', right? 'I'm the boss', right? (Sanne, author's translation)

Nonetheless, even with free choice, the service must be offered according to what is permitted in the care assessment; no one can receive more help than what the care assessor has written in the care plan. As Anne, a municipal home helper, comments:

I've talked with one of those users that I visit regularly and she says 'I don't care who does the cleaning, 'cause in the end I don't get more time. I get the same service, no matter who I choose' so she stayed with us. And she is right, you know. (Anne-Mette, municipal home helper, author's translation)

Even so, free choice entails new assumptions about user-influence and responsibility, thereby also stretching the role of the elderly as the one who must identify and assess quality. The expectation that competition between public and private providers will lead to better quality includes the user's choosing the 'best' provider. Thus, the user now has part of the responsibility for developing quality. If the user believes that the quality of his or her care is 
insufficient, that user is entitled - but also expected - to change provider. The user must then also answer for the consequences of his or her choices: if the users remain with a provider who continues to provide care, it is partly a consequence of her own actions, because the user could have chosen differently. Thus, the discourse of freedom does not acknowledge the new risks which are created, namely, the freedom to make bad or wrong choices.

\title{
Equal choice for all - but not equal outcomes
}

The choice option also includes an assumption that choice is equal for all. In this way choice is in line with the universalist notion of the welfare state whereby everyone, regardless of age, gender or social class, is entitled to exercise choice. In reality, however, how choice is made differs considerably amongst users. It is primarily new users who choose private for-profit providers, presumably because they must exercise choice when entering the system whereas users already in the system may be offered the choice, but do not have to do so - and this difference matters:

\begin{abstract}
I would say that most of those who have received services prior [to the free choice], and whom we call, are typically those who decide to stay where they are. There are few who decide to move. The new ones, on the other hand, who might need temporary care following a surgical procedure or something else, very often, once they take a look at it, chooses a private provider just as often as a municipal one. (Kirsten, care assessor, author's translation)
\end{abstract}

New users not only arrive with no prior attachment to a particular provider, but are often also less frail and therefore less risk-adverse. The outcome of choice is in this way not equal; the choice is made on the basis of care needs, where care dependency also influences the choice:

\begin{abstract}
There is this tendency of those who are most frail and least self-reliant to choose the municipal provider. While those who do well and manage somewhat on their own primarily choose the private. It's like: 'Well, I am in safe, municipal hands if something should go wrong'. (Josephine, care assessor, author's translation)
\end{abstract}

In the early days of free choice, then, mainly new users chose a private forprofit provider. Often these users received only practical assistance. As expected, however, this practice changed over time: in 2004, two per cent of users receiving personal care and 22 per cent of users receiving practical assistance received help from a private for-profit provider (Den Sociale Ankestyrelse, 2004). In 2009, 31 per cent of recipients of practical assistance used a private for-profit provider, compared to only five per cent of recipients of personal care (Danmarks statistik, n.d.).

Part of the reason for the increase in the use of private for-profit provision of care may be that users today are more acquainted with the free-choice option and the local companies operating in their area. Nonetheless, many users remain unaware of the possibility of choosing between providers, and a survey in 2009 has shown that only 65 per cent of users know that they can exercise this right (Capacent, 2009). Presumably these users are mainly those who have received services for many years and therefore have not had to choose. 


\section{Exiting a care relation}

However, even if users know about the possibility of choosing, exercising choice may not be a straightforward matter. The user can choose as many providers (and as often) as he or she likes, but changing a care provider constitutes stating that the quality of the present provider is insufficient. However, the consequences of using their option to exit may not be clear to the user, as Mille, who works as a care assessor, explains: 'I also experience that they then ask: What if I need personal care? Will you be mad at me for choosing [a private for-profit provider]?' (author's translation)

Moreover, for most users of care, their major concern is not whether they are entitled to exit or to end a care relationship, but rather to maintain one, as Cathrine, a user of municipal home help, says: 'I think it would be good if we could have the same home helper more than once' (Author's translation). Often what is at stake is that during the day or week the elderly will be visited by many different care workers. Continuity in staff is rare, not only for those elderly who receive services several times a day, for whom care is often provided by more than one care worker. A recent nationally representative survey of home-help users has shown that one in five users of home help (18.2 per cent) is either very dissatisfied or dissatisfied with the number of care workers (Capacent, 2009).

Dissatisfaction is more pronounced amongst users who receive both personal and practical care, and these recipients of care are thus more likely to receive a visit from the home helper several times a day. Here 22.4 per cent of users express dissatisfaction, in comparison to users of practical care only, where 17.1 per cent are dissatisfied. As we have seen, most users (95 per cent) of personal care use a public provider and a higher proportion of users of municipal services are dissatisfied with the continuity of staff (21.0 per cent) compared to users of private for-profit providers (10.2 per cent).

Even if free choice is associated with the possibility of exiting and of maintaining a care relationship, private for-profit providers are nevertheless gaining ground because they are able to deliver continuity in care and to promote their services on the basis of that activity. Staff continuity is found in other studies to be the most desired attribute of quality from both older persons and care workers (Edebalk et al., 1995; Rostgaard \& Thorgaard 2007). According to Monica, a care assessor, users do appreciate the same person coming to visit: 'This is something the elderly appreciates. That is, that it is the same person' (author's translation). Monica states that it is not only the same person but also a person with certain characteristics that private forprofit providers can guarantee. 'Some of the private ones also promote themselves by saying that the care workers working with them are mature ladies, instead of the young lasses that the municipality sends. What they mainly emphasize is that it is the same person and that you yourself can decide whether you want a man or a woman' (author's translation).

But the choice of a certain person or a person with certain characteristics, such as experience with care work, is not part of the assumptions underlying free choice of home-help provider. Although some private for-profit providers seem also to guarantee a choice of staff member, this certainly seems not to be practised amongst municipal home-help providers. As Gitte and Elsebeth, both municipal home helpers, explain: 
Well, I have a funny story: When free choice was introduced, one of our users thought you could choose which home help you'd want to come and help you from the municipal provider [everyone laughs]. Because it was 'free choice', so we let him, but we normally don't. It depends on who has time and so on." (Gitte, author's translation)

Yes, I experienced the same. And then she said: 'I would like to hire you.' Yes, yes. [they laugh] They misunderstand it, yes, they do. (Elisabeth, author's translation)

\section{Care in the name of freedom}

A final implicit assumption when autonomy is communicated as a precondition of quality of care is that care is a commodity like any other, which the user decides to make use of. With several providers offering services, the user must from the beginning act as a critical consumer who is sceptical about the 'commodity' which she is offered, that is the kind of care which the provider can offer. This assumption, therefore, rests on the belief that the user must pay attention to whether he or she has received the best quality. Rather than a relationship build on trust, the market relationship assumes that the consumer keeps a certain distance and continuously reflects on whether another commodity might be better.

However, elderly care entails a very personal and often very intimate relationship between user and care giver. Care takes place in the individual's private home and involves very private and intimate activities. This situation requires that a certain trust be in place between care user and care giver and that the care giver understands and respects the elderly's dignity, vulnerability, and frailty, and such a relationship often requires time to develop.

As Rønning (2004) states, however, it seems as if a battle of the very soul of care has been taking place these past years. This battle stands between the view of care as a commodity, where the issues concern cost-efficiency, the standardization of care needs, and the price-setting of care, and the view that considers care as an encounter between care recipient and care provider, which is based in a social relationship between the two. As the assumption behind free choice is that the care relationship can be terminated and replaced, it ignores the process involved in establishing such a relationship.

It also overlooks entirely the fact that care needs cannot be postponed until something better is within reach. It is not possible, as with other commodities, for the elderly to 'shop around' until something better comes along. Nevertheless, the assumption that care can be treated as a commodity is gaining ground, as this conversation between Albert, who receives private forprofit home help, and three private home helpers illustrates:

Albert: 'When you are at my age, one doesn't have much family, and then one might need someone to talk to. There isn't much of that.'

Sidsel (private home helper): 'But have you ever considered that when you receive care from a private provider, you can buy extra time? Have you thought about that?'

Albert: 'I know that, but that's not it. I can't buy time to have someone sit and chat over a cup of coffee.'

Astrid (private home helper): 'Oh yes. You certainly can.' 
Mette-Marie (private home helper): 'You decide yourself what you want us to spend time on. You decide what we should do during the extra time that you purchase. It is not we who decide what to do. It's your money. So it is only you who has to decide what is done.'

\title{
Better quality?
}

Has the introduction of private for-profit providers of home care led to the expected increase in quality? According to one care assessor, private for-profit providers provide more stable services and a difference in the approach to the user in that private for-profit providers appreciate to a higher degree that they are deliberately chosen:

\begin{abstract}
And the municipality is not service minded or provide stability well enough. We are not good enough at this either. And we are not good at getting out there and selling ourselves. Well, the private providers in our municipality, they come visiting, every time they have a new user, and say: Thank you for choosing us'...Well, you know, the municipality would never dream of doing this. (Mille, care assessor)
\end{abstract}

Users themselves acknowledge the possibility of choosing a provider: 57 per cent thus responded that having a choice of provider is either very important or important to them (Capacent, 2009). Nevertheless, ratings of quality show little difference between how users rate the care from the two provider types. Amongst users receiving practical assistance, 85.8 per cent of users of municipal home care are either satisfied overall or very satisfied with the services overall, whereas the share is only 86.5 per cent for users of private for-profit home care. Amongst users of personal care, 92.2 per cent of users of municipal home care are satisfied overall or very satisfied, compared to 85.7 per cent of users of private for-profit home care (Capacent, 2009).

\section{Conclusion}

The introduction of consumerism in social policy in Denmark, exemplified by the introduction of free choice in home care, appears to be part of an overall agenda of re-shifting the problematics of the traditional welfare state and, in particular, of overcoming ideological resistance to privatization. Initially, notions of welfare-state failure gave way to the new notion of consumerism in Denmark. The criticism aimed at the welfare state has come about because various paradoxes have been created over time and the welfare state has become increasingly complex. Paradoxes have arisen 1 ) because the welfare state at one and the same time has increased the politicization of problems while being accused of public welfare inefficiency and bureaucracy; 2) because both the political goal of unity and the goal of producing differentiated and individualized welfare solutions exist; and 3) because the welfare state has had difficulty finding its footing in the search for legitimacy of public intervention while also trying to secure individual autonomy and involvement.

This article has described how the choice was seen to be the 'overarching' answer to these three paradoxes. It was supposed to solve the paradox of how to empower the disempowered user of care (through active involvement); it was supposed to result in better user-led quality of care; it was supposed to provide more cost-efficient services (through the introduction of the market 
principle); and lastly it was to help develop a care market, which would match with the ideology of the present government (privatization).

Inherent in the principle of the free choice are a number of assumptions about the role of the elderly as users and the responsibilities they are assigned in the consumerist model. This article has described how elderly users, despite their frailty, are expected to become actively involved in the identification of their needs and of the provider that can best meet these needs. The consumerist approach also gives these users room for expression of satisfaction through changing providers. Users are now 'equal', because the state guarantees that choice will be available for all across gender, ethnicity, income, class, and local authority, and the user is also made the co-producer of what care relationships are worth continuing (and in this way becomes the quality assurer).

This article argues that the consequences of introducing free choice are that users are given an opportunity to express themselves through choosing or rejecting a provider. However, the elderly themselves most want to choose the person who provides care and to obtain some continuity in this care relationship. They are much less concerned with their 'ownership' of the provider. Users also rate quality of care to be more or less the same, regardless of whether the care comes from a private for-profit or public provider.

It has also been argued that there is no consideration about the specific nature of care and dependency in the consumerist approach. Care is treated just like any other commodity and the elderly just like any other consumer. Yet for any market to be efficient it requires that the user exercises critical judgement about the purchased good. Mutual distrust is necessary for the market to operate most rationally, and consumers must always be on the outlook for a better or cheaper product if the market terms are to be fulfilled. But care, in contrast, also entails crucial issues of relationships, trust, and dependency.

Overall, the consumerist way of thinking also changes the conditionality of the welfare state and its subjects because this way of thinking creates new forms of responsibility and dependencies. While the regime of choice was intended to empower the disempowered individual, it also conditions the individual as a self-responsible agent, that is, responsible for his and her own welfare. Greater autonomy also implies the risk of choosing poorly or choosing too often, thereby becoming a bad risk that providers seek to avoid. Thus the discourse of freedom disregards new risks: the freedom to make bad or wrong choices.

\section{References}

Blomberg, S., Edebalk, P. G., \& Petersson, J. (2000). The withdrawal of the welfare state: elderly care in Sweden in the 1990s. European Journal of Social Work. 3(2), 179-190.

Blomqvist, P. (2004). The choice revolution: privatization of Swedish welfare services in the 1990s. Social Policy \& Administration, 38(2), 139-155.

Edebalk, P. G. \& M. Svensson (2005). Kundval för äldre och funktionshindrade $i$ Norden. Konsumentperspektivet [Customer choice for elderly and disabled people in the Nordic countries]. Köpenhamn: Nordiska ministerrådet, Tema Nord, 2005: 507. 
Capacent. (2009). Brugerundersøgelse om hjemmehjælp til beboere i eget hjem og i plejebolig/plejehjem [A user survey on home help to residents in their own home and in nursing homes]. København: Indenrigs \& Socialministeriet. Retrieved Maj 12, 2011 from http://www.sm.dk/Temaer/velfaerdsudv/dokumentation/aeldreomraadet/Sider/St art.aspx

Clarke, J. \& Newman, J. (1997). The managerial state. London: Sage.

Danmarks Statistik. (n.d.). Statistik banken, www.dst.dk.

Dybbroe, B. (2008). Crisis of care in a learning perspective. In S. Wrede, L. Henriksson, H. Høst, S. Johansson \& B. Dybbroe (Eds). Care work in crisis: reclaiming the Nordic ethos of care (pp 41-48). Lund: Studentlitteratur.

Edebalk, P.G., Samuelsson, G., \& Ingvad, B. (1995). How elderly people rank-order the quality characteristics of home services. Ageing and Society 15(1), 83-102.

Edebalk, P. G. \& M. Svensson (2005). Kundval för äldre och funktionshindrade $i$ Norden. Konsumentperspektivet [Consumer choice for the elderly and the physically challenged in the Nordic countries: a consumer perspective]. Köpenhamn: Nordiska ministerrådet, Tema Nord, 2005: 507.

Evers, A. (2003). Current strands in debating user involvement in social services. Giessen: Justus-Liebig-Universität. Discussion Paper for the Group of Specialists on User Involvement in Social Services (CS-US) - Council of Europe. September 2003.

Finansministeriet. (2001). Velfærd og valgfrihed: et reformprogram [Welfare and freedom of choice: a reform programme]. København: Finansministeriet.

Foster, P. \& Wilding, P. (2000). Whither welfare professionalism? Social Policy and Administration 34(2), 143-59.

Greve, C. (2004). Frit valg-politk i Danmark [Free-choice policy in Denmark]. Nordisk Administrativt Tidskrift 85(2). København: DJøF.

Højlund, H. (2002). Velfærdsforskydninger: dokumentation, fleksibilitet og delagtiggørelse på ældreområdet [Shifts in welfare: documentation, flexibility, and involvement for the elderly]. København: Handelshøjskolen, Institut for Ledelse, politik og filosofi, WP 12/2002.

Kommunernes Landsforening. (2004). Økonomisk perspektiv om smidigere regler for frit valg på ældreområdet [An economic perspective on more flexible rules for free choice for the elderly]. København: KL.

Kremer, M. (2004). Consumers in charge of care: The Dutch Personal Care Budget and its impact on the market, professionals and the family. European Societies, $8(3), 385-401$.

Kröger, T. (1997). Local government in Scandinavia: autonomous or integrated in the welfare state?. In J. Sipilä (ed.), Social Care Services: The Key to the Scandinavian Welfare Model (pp. 95-108). Aldershot: Avebury.

Lolle, H. (1999). Serviceudgifter og brugertilfredhedshed i danske kommuner [Service costs and user satisfaction in Danish municipalities]. Ålborg: Ålborg University Press.

Melander, P. (2008). Det fortrængte offentlige lederskab - Offentlig ledelse efter New Public Management [The subdued public leadership: public leadership after New Public Management]. København: Jurist- og Økonomforbundets Forlag. 
Pollitt, C. \& Bouckaert, G. (2000). Public management reform: a comparative analysis. Oxford: Oxford University Press.

Regeringen. (2004). Frihed til at vælge [The freedom to choose]. København: Statsministeriet.

Rostgaard, T. (2006). Constructing the care consumer: free choice of home care for the elderly in Denmark. European Societies, 8(3), 443-463.

Rostgaard T. \& Thorgaard, C. (2007). God kvalitet i ældreplejen: sådan vægter de ældre, plejepersonale og visitatorer [Good quality in elderly care: how the elderly, care workers, and care assessors evaluate it]. SFI 07:27.Copenhagen: SFI - Det Nationale Forskningscenter for Velfærd.

Rønning, R. (2004) Omsorg som vare? Kampen om omsorgens sjel i norske kommuner [Care as commodity? The battle for the soul of caring in Norwegian municipalities]. Oslo: Gyldendal Norsk Forlag.

Stevens, M., Glendinning, C., Jacobs, S., Moran, N., Challis, D., Manthorpe, J., \& Wilberforce, M. (2011). Assessing the role of increasing choice in English social care services. Journal of Social Policy 40(2), 257-274.

Trydegård, G. (forthcoming). Care work in changing welfare states: Nordic care workers' experiences, in the European Journal of Ageing.

Vabø, M. (2009). Home care in transition: the complex dynamic of competing drivers of change in Norway. Journal of Health Organisation and Management, 23(3), 346-359. 